\title{
ANALISIS FAKTOR-FAKTOR YANG MEMPENGARUHI MOTIVASI, PERSEPSI DAN SIKAP NASABAH TERHADAP KEPUTUSAN PEMBELIAN PRODUK ASURANSI PENDIDIKAN
}

\author{
Endang Saryanti ${ }^{1)}$ \\ S1 Manajemen Sekolah Tinggi Ilmu Ekonomi Adi Unggul Bhirawa \\ e-mail : endsary@gmail.com
}

\begin{abstract}
ABSTRAK
Tujuan penelitian ini adalah untuk menganalisis signifikansi pengaruh motivasi, persepsi dan sikap secara parsial dan simultan terhadap keputusan pembelian produk asuransi pendidikan Sequislife di Solo.

Penelitian ini di lakukan dengan metode kuesioner terhadap 75 responden nasabah asuransi Sequislife di Solo yang diperoleh dengan menggunakan teknik pengambilan sampel yaitu non probability sampling dengan jenis yang di gunakan adalah purposive sampling. Kemudian dilakukan analisis terhadap data- data yang di peroleh berupa analisis kualitatif dan kuantitatif, uji asumsi klasik, regresi linier berganda, uji t, uji F dan uji koefisien deteminasi $\left(\mathrm{R}^{2}\right)$.

Penelitian ini menghasilkan persamaan regresi $\mathrm{Y}=5,006+0,330 \mathrm{X}_{1}+0,204 \mathrm{X}_{2}+0,252 \mathrm{X}_{3}$. Berdasarkan analisis tersebut dapat di ketahui bahwa motivasi, persepsi dan sikap nasabah berpengaruh positif terhadap keputusan pembelian produk asuransi pendidikan Sequislife di Solo. Hasil uji t menunjukkan bahwa motivasi, persepsi dan sikap nasabah secara parsial berpengaruh signifikan terhadap keputusan pembelian produk asuransi pendidikan Sequislife di Solo. Hasil uji secara serempak (uji F) dengan signifikansi 0,000<0,05 sehingga diperoleh hasil motivasi, persepsi dan sikap nasabah secara simultan berpengaruh terhadap keputusan pembelian produk asuransi pendidikan Sequislife di Solo. Hasil uji koefisien determinasi $\left(\mathrm{R}^{2}\right)$ didapatkan variabel motivasi, persepsi dan sikap nasabah memberikan kontribusi sebesar 62,6\% terhadap keputusan pembelian produk asuransi pendidikan Sequislife di Solo sedangkan sisanya 37,4\% di pengaruhi oleh faktor lain diluar variabel yang di teliti.
\end{abstract}

Kata kunci : motivasi, persepsi, sikap dan keputusan pembelian

\section{ABSTRACT}

The purpose of this study is to analyze the significance of the influence of motivation, perceptions and attitudes partially and simultaneously to the purchase decision of education insurance products Sequislife in Solo.

This research is done by questionnaire method to 75 respondents of insurance customers Sequislife in Solo obtained by using sampling technique that is non probability sampling with the type that is used is purposive sampling. Then analyzed the data obtained in the form of qualitative and quantitative analysis, classical assumption test, multiple linear regression, $t$ test, $F$ test and detemination coefficient test (R2).

This research yields regression equation $Y=5,006+0,330 X 1+0,204 X 2+0,252 X 3$. Based on the analysis it can be seen that the motivation, perception and attitude of the customer positively affect the purchase decision of education insurance products Sequislife in Solo. The result of t test shows that the motivation, perception and attitude of the customer partially have significant effect to the purchasing decision of Sequislife education insurance product in Solo. The result of simultaneous test (F test) with significance 0.000 0,05 so that the result of motivation, perception and attitude of customer simultaneously have an effect on to purchasing decision of Sequislife education insurance product in Solo. The result of determination coefficient test (R2) got the variable of motivation, perception and attitude of customer give contribution equal to 62,6\% to decision of purchasing of insurance product of education of Sequislife in Solo while the rest 37,4\% influenced by other factor outside of variable in carefully.

Keywords: motivation, perception, attitude and purchase decision 


\section{PENDAHULUAN}

Asuransi pendidikan merupakan salah satu jenis asuransi jiwa yang mengandung unsur investasi, yakni pada tahapan-tahapan pendidikan anak, maka ada sejumlah nilai tunai yang bisa diambil untuk membayar biaya pendidikan anak. Karena itu, biasanya nilai tunai pada asuransi pendidikan hanya bisa diambil pada saat tahapan pendidikan anak jatuh tempo. Misalnya saat akan membayar uang pangkal masuk sekolah SD, SMP, SMA, dan perguruan tinggi. Hal itu seiring dengan meningkatnya kesadaran masyarakat atas pendidikan. Pada saat ini setidaknya ada tiga hal utama yang menyebabkan masyarakat menjadikan asuransi sebagai instrumen investasi, yakni kesehatan, pendidikan, dan pensiun. Namun, pada masa mendatang tidak menutup kemungkinan alasan pendidikan menjadi hal utama bagi masyarakat untuk memegang polis asuransi. Biaya pendidikan yang terus meningkat membuat masyarakat mencari alternatif pembiayaan bagi pendidikan anakanaknya pada masa mendatang. Walaupun tidak menutupi semua kebutuhan biaya pendidikan, dengan adanya asuransi pendidikan masyarakat akan terbantu. Asuransi pendidikan tidak hanya menjamin ketika orang tua mengalamin kesulitan keuangan tetapi asuransi pendidikan juga menjamin ketika orang tua meninggal atau lumpuh sehingga menyebabkan orang tua tidak bisa mencari nafkah (Rawaini ; 2014). Rasa khawatir akan pendidikan yang semakin mahal, membuat keluarga membutuhkan jaminan akan hal tersebut di masa yang akan datang. Orang tua sebagai seorang konsumen membutuhkan suatu produk yang dapat memberikan rasa aman dan menjamin keberlangsungan pendidikan bagi anak-anaknya. Asuransi pendidikan bisa menjadi alternatif bagi orangtua yang ingin menjamin masa depan anak-anaknya. Asuransi pendidikan merupakan bagian dari asuransi jiwa yang mempertanggungkan jaminan pendidikan terhadap nasabah yang dipertanggungkan. Jenis asuransi ini cukup menjadi focus dan perhatian tersendiri dari tenaga pemasar khususnya di Solo karena hal ini kemungkinan masyarakat pada umumnya belum memahami arti dan manfaat asuransi tersebut khususnya bagi masyarakat menengah kebawah yang sekiranya berpotensi, sehingga perlu di bukakan kembali pikran dan pengetahuan mereka tentang pentingnya asuransi pendidikan bagi anak di masa mendatang. Di antara perusahaan asuransi di Indonesia khususnya di Solo, yang memiliki produk asuransi pendidikan salah satunya adalah asuransi Sequislife.

Faktor psikologi konsumen menjadi dasar dalam minat beli konsumen akan suatu produk dan jasa. Seperti halnya motivasi yang merupakan dorongan untuk melakukan suatu tindakan. Suatu motivasi yang datangnya dari dalam membentuk kesadaran akan pentingnya sebuah pendidikan bagi masa depan anak sebagai persiapan untuk pendidikannya di masa mendatang. Lain halnya motivasi yang datang dari luar yaitu pengaruh lingkungan adalah fungsi dari perusahaan asuransi pendidikan mengajak masyarakat untuk mewujudkan masa depan anak melalui kepastian atas jaminan terhadap pendidikan.

Faktor psikologi yang kedua adalah persepsi, dimana seseorang cenderung menilai suatu obyek dari apa yang dilihatnya dengan sudut pandang yang berbeda pada setiap orang. Ada yang menilai bahwa asuransi mahal dan hasilnya tidak pasti, proses klaim lambat dan di persulit, mengikuti asuransi berarti menambah beban pengeluaran. Yang perlu di ketahui bahwa premi yang di bayarkan tidak semahal yang di pikirkan, tergantung dari beberapa faktor di dalamnya dan ketika terjadi suatu resiko asuransi akan melindungi dan menjaminnya. Permasalahan yang sekarang di temui adalah masyarakat lebih memilih menggunakan uang cadangannya daripada mengikuti program asuransi. Sehingga mulai dari sini persepsi masyarakat perlu di ubah untuk sedikit memahami tentang asuransi bahwa asuransi tidak akan merugikan masyarakat malah sebaliknya membantu dan menjamin finansial dalam keluarga. 
Faktor psikologi yang ketiga adalah sikap. Potensi asuransi pendidikan sangat besar manfaatnya, khususnya untuk meningkatkan kapasitas pendidikan dimana salah satu indikator utama pembangunan adalah tingkat pendidikan yang telah dimiliki oleh masyarakat. Semakin tinggi pendidikan masyarakat maka kegiatan pelaksanaan pembangunan akan semakin baik. Pada tingkat kesejahteraan atau pendapatan masyarakat yang rendah, menjadikan asuransi bukan sebagai kebutuhan atau gaya hidup. Itulah sebabnya menyisihkan sebagian pengeluaran untuk pembayaran premi yang identik dengan menabung tidak mampu di anggarkan. Memang manfaatnya belum terasa langsung namun baru bisa di rasakan nanti. Walaupun masyarakat mungkin sudah mengenal asuransi tetapi belum merasa butuh untuk memilikinya. Sikap ini yang menjadikan masyarakat cenderung menunda untuk memiliki asuransi. Dari sinilah dapat dilihat bahwa sikap konsumen baik dari pengetahuan, tingkat kesejahteraan sampai pada kebutuhan akan produk asuransi sangat penting bagi industri asuransi dan sikap konsumen tersebut yang nantinya akan mendorong keputusan konsumen untuk membeli produk asuransi sebagai jaminan perlindungan.

Berdasarkan latar belakang ini, peneliti tertarik untuk mengadakan penelitian lebih lanjut dalam bentuk skripsi yang berjudul "Pengaruh Motivasi, Persepsi dan Sikap Nasabah Terhadap Keputusan Pembelian Produk Asuransi Pendidikan Sequislife di Solo"

\section{TUJUAN PENELITIAN}

a. Untuk mengetahui secara empiris pengaruh motivasi terhadap pembelian produk asuransi pendidikan Sequislife di Solo.

b. Untuk mengetahui secara empiris pengaruh persepsi terhadap pembelian produk asuransi pendidikan Sequislife di Solo.

c. Untuk mengetahui secara empiris pengaruh sikap nasabah terhadap pembelian produk asuransi pendidikan Sequislife di Solo.

\section{MANFAAT PENELITIAN}

a. Bagi Perusahaan

Penelitian di harapkan dapat di gunakan sebagai bahan masukan dan evaluasi bagi kebijakan perusahaan dalam menentukan strategi penjualan asuransi.

b. Bagi Penulis

Hasil penelitian ini di harapkan dapat memberikan kesempatan untuk menambah pengetahuan dan wawasan dalam pembelian asuransi sebagai nasabah serta pengetahuan mengenai asuransi.

c. Bagi Pihak Lain

Hasil penelitian ini dapat digunakan sebagai bahan referensi bagi pembaca dan dapat memberikan informasi bagi penelitian lain yang berkaitan dalam bidang pemasaran. 


\section{KERANGKA PEMIKIRAN}

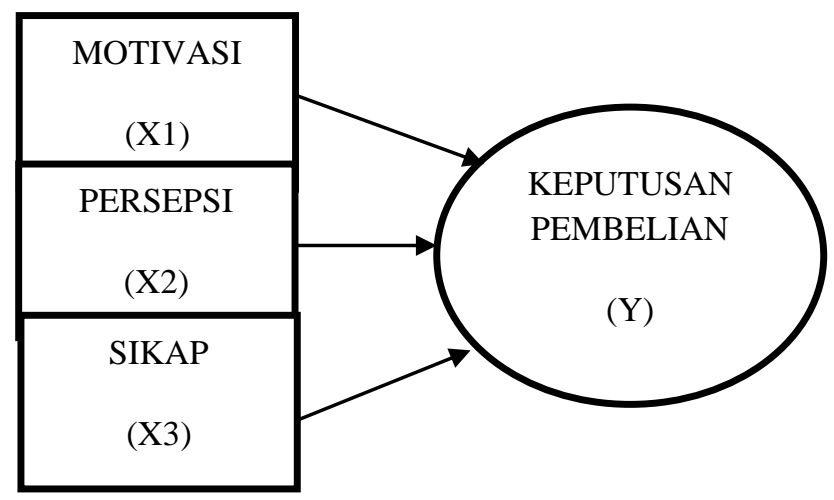

Sumber : Wahyuni (2008), Romika Aan Nurdianto (2010), Safinatun Najah (2016)

\section{HIPOTESIS}

H1 : Motivasi berpengaruh signifikan terhadap pembelian produk asuransi pendidikan Sequislife di Solo.

H2 : Persepsi berpengaruh signifikan terhadap pembelian produk asuransi pendidikan Sequislife di Solo.

H3 : Sikap berpengaruh signifikan terhadap pembelian produk asuransi pendidikan Sequislife di Solo.

\section{METODE PENELITIAN}

Dalam penelitian ini lokasi yang dipergunakan untuk penelitian yaitu di PT. Asuransi Jiwa Sequis life Solo.Variabel yang diteliti adalah motivasi, persepsi dan sikap nasabah serta keputusan pembelian produk asuransi pendidikan. Sampel yang di gunakan dalam penelitian ini sebanyak 75 dengan menggunakan rumus Slovin dan dengan menggunakan teknik non probability sampling. Untuk metode analisis data dalam penelitian ini menggunakan uji validitas, reliabilitas, uji asumsi klasik, regresi linier berganda dan uji hipotesis penelitianyang terdiri dari uji t, uji $\mathrm{F}$ dan uji koefisien determinasi.

\section{HASIL DAN PEMBAHASAN}

\section{Uji Validitas}

Dalam penelitian ini terdiri dari tiga variabel bebas yaitu motivasi, persepsi dan sikap serta satu variabel terikat yaitu keputusan pembelian asuransi pendidikan. Dari uji validitas terbukti semua variabel bebas mempunyai $r_{\text {hitung }}$ lebih besar dari $r_{\text {tabel }}$ (signifikansi pada level $0,05)$ merupakan item yang valid dalam menjelaskan variabel yang diuji.

\section{Uji Reliabilitas}

Hasil uji reliabilitas dapat diketahui bahwa indikator dari variabel motivasi, persepsi, sikap dan keputusan pembelian adalah reliabel yang memiliki nilai Alpha Cronbach secara 
berturut- turut yaitu 0,730 untuk motivasi ; 0,839 untuk persepsi ; 0,835 untuk sikap dan 0,637 untuk keputusan pembelian. Karena koefisien dari Alpha Crobach mempunyai nilai kritis 0,60 maka dapat dikatakan reliabel atau handal sehingga dapat di gunakan sebagai instrumen penelitian.

\section{Uji Asumsi Klasik}

Uji Normalitas

Dari grafik normal probability plots terlihattitik-titikmenyebarberhimpitdisekitargaris diagonal danhalinimenunjukkanbahwa residual terdistribusi secara normal.

UjiMultikolinieritas

\begin{tabular}{|lll|}
\hline Model & $\mathrm{t}$ & $\mathrm{VIF}$ \\
\hline Motivasi & 2,761 & 2,655 \\
Persepsi & 3,586 & 1,537 \\
Sikap & 2,529 & 2,578 \\
\hline
\end{tabular}

Berdasarkan table masing- masing variable bebas memiliki nilai VIF lebih kecil dari 10 dan mempunyai nilai toleransi lebih besar dari 0,10 . Sehingga dapat disimpulkan tidak terjadi multikolinieritas.

Uji Autokorelasi

Dapat di lihat bahwa angka Durbin Watson adalah 1,816 yang akan bandingkan dengan tabel DurbinWatson dengan menggunakan derajat kepercayaan 5\%. Maka dalam tabel Durbin Watson di peroleh angka $d_{U} 1,709$ dan 2,291 dari $\left(4-d_{U}\right)$. Dalam table terlihat bahwa nilai DW 1,816 lebih besar dari $\mathrm{d}_{\mathrm{U}}$ dan lebih kecil dari $\left(4-\mathrm{d}_{\mathrm{U}}\right)$ atau $1,816>1,709<2,291$.Nilai $\mathrm{DW}$ terletak antara batas atas atau $\left(\mathrm{d}_{\mathrm{U}}\right)$ dan $\left(4-\mathrm{d}_{\mathrm{U}}\right)$, maka koefisien autokorelasi sama dengan nol, sehingga dapat di simpulkan tidak ada autokorelasi.

Uji Heteroskedastisitas

Dari grafik tidak ada pola yang jelas sertatitik - titik menyebar secara acak(random)baik di atasmaupun di bawah angka 0 pada sumbu Y. Hal ini dapat disimpulkan bahwa tidak terjadi heteroskedastisitas pada model regresi ini.

\section{Regresi Linier Berganda}

\begin{tabular}{|ll|}
\hline Model & $\begin{array}{l}\text { Standardized Coefficients } \\
\text { Beta }\end{array}$ \\
\hline Motivasi &, 320 \\
Persepsi &, 316 \\
Sikap &, 289 \\
\hline
\end{tabular}

Dari hasil pengujian dapat disimpulkan bahwa dari ketiga variabel independen yang di uji secara individual yang paling dominan dalam mempengaruhi keputusan pembelian produk 
asuransi pendidikan Sequislife di Solo adalah motivasi dengan koefisien 0,320. Variabel berikutnya yang memiliki peran cukup besar adalah persepsi dengan koefisien 0,316. Selanjutnya variabel sikap memiliki peran paling kecil dengan koefisien 0,289. Dengan demikian semua variabel independen berpengaruh positif terhadap keputusan pembelian produk asuransi pendidikan Sequislife di Solo.

\section{Uji Hipotesis}

Uji t

\begin{tabular}{|lll|}
\hline Model & $\mathrm{t}$ & Sig. \\
\hline Motivasi & 2,761 &, 007 \\
Persepsi & 3,586 &, 001 \\
Sikap & 2,529 &, 014 \\
\hline
\end{tabular}

Nilai uji t antara motivasi terhadap keputusan pembelian sebesar 2,761 dengan tingkat signifikansi $0,007 \leq \alpha 0,05$ sehingga menunjukkan di terimanya hipotesis yang menyatakan motivasi berpengaruh signifikan terhadap keputusan pembelian produk asuransi pendidikan Sequislife di Solo.

Nilai uji $\mathrm{t}$ antara persepsi terhadap keputusan pembelian sebesar 3,586 dengan tingkat signifikansi $0,001 \leq \alpha 0,05$ sehingga menunjukkan di terimanya hipotesis yang menyatakan persepsi berpengaruh signifikan terhadap keputusan pembelian produk asuransi pendidikan Sequislife di Solo.

Nilai uji $\mathrm{t}$ antara sikap terhadap keputusan pembelian sebesar 2,529 dengan tingkat signifikansi $0,014 \leq \alpha 0,05$ sehingga menunjukkan di terimanya hipotesis yang menyatakan sikap berpengaruh signifikan terhadap keputusan pembelian produk asuransi pendidikan Sequislife di Solo.

Uji F

\begin{tabular}{|lll|}
\hline Model & F & Sig. \\
\hline Motivasi & & \\
Persepsi & 42,334 &, $000^{\mathrm{a}}$ \\
Sikap & & \\
\hline
\end{tabular}

Hasil uji serempak (Uji F) di ketahui besarnya nilai $F_{\text {hitung }}$ adalah 42,334 dengan nilai signifikansi $0,000<0,05$. Sehingga pada hasil uji $\mathrm{F}$ dapat diketahui bahwa variabel motivasi, persepsi dan sikap nasabah secara simultan berpengaruh terhadap keputusan pembelian produk asuransi pendidikan Sequislife di Solo.

Uji Koefisien Determinasi $\left(\mathrm{R}^{2}\right)$

Berdasarkan hasil koefisien determinasi maka di peroleh nilai yang positif dari Adjusted R Square yaitu 0,626 yang berarti bahwa pengaruh yang di berikan variabel bebas yang berupa motivasi (X1), persepsi (X2), dan sikap (X3) terhadap variabel dependen yaitu keputusan pembelian produk asuransi pendidikan Sequislife di Solo sebesar 62,6\% sedangkan sisanya yaitu $37,4 \%(100 \%$ - 62,6\%) di pengaruhi oleh faktor lain diluar variabel yang diteliti. Seperti misalnya kualitas pelayanan, promosi, kesadaran merek dan citra merek. 


\section{KESIMPULAN DAN SARAN}

Dari hasil uji regresi linier berganda dapat disimpulkan variabel motivasi, persepsi dan sikap nasabah berpengaruh secara positif terhadap keputusan pembelian produk asuransi pendidikan Sequislife di Solo.

Dari hasil uji t dapat disimpulkan bahwa variabel motivasi secara parsial berpengaruh signifikan terhadap keputusan pembelian produk asuransi pendidikan Sequislife di Solo. Variabel persepsi secara parsial berpengaruh signifikan terhadap keputusan pembelian produk asuransi pendidikan Sequislife di Solo. Variabel sikap secara parsial berpengaruh signifikan terhadap keputusan pembelian produk asuransi pendidikan Sequislife di Solo.

Dari hasil uji F Dapat disimpulkan bahwa hasil secara serempak (Uji F) dapat disimpulkan bahwa variabel motivasi, persepsi dan sikap nasabah secara simultan berpengaruh terhadap keputusan pembelian produk asuransi pendidikan Sequislife di Solo.

Dari hasil uji koefisien determinasi $\left(\mathrm{R}^{2}\right)$ variasi keputusan pembelian di jelaskan oleh variabel motivasi, persepsi dan sikap yang memberikan kontribusi sebesar 62,6\% sedangkan sisanya 37,4\% di jelaskan oleh variabel- variabel lain diluar variabel yang di teliti.

\section{SARAN}

Bagi nasabah hendaknya di dalam melakukan keputusan pembelian berpedoman pada sikap yang perlu di tingkatkan mengingat koefisien variabel sikap cukup kecil pengaruhnya terhadap keputusan pembelian sehingga di harapkan dapat memilih produk asuransi yang tepat dan sesuai dengan kebutuhan.

Bagi perusahaan hendaknya tetap mempertahankan kualitas dari produk asuransi agar nasabah tetap loyal sehingga dapat menambah polis asuransi.

Bagi peneliti lain hendaknya dapat mengembangkan variabel yang lebih luas mengingat besarnya proporsi atau sumbangan variabel bebas terhadap variabel terikat sebesar 62,6\% dan sisanya masih terdapat $37,4 \%$ yang tidak ikut di teliti. Seperti misalnya kualitas pelayanan, promosi, kesadaran merek dan citra merek.

\section{DAFTAR PUSTAKA}

Assael, Henry. 2001. Consumer Behavior 6th Edition. New York: Thomson Learning.

Azwar S. 2003. Sikap Manusia, Teori dan Pengukurannya.Yogyakarta : Pustaka Pelajar

Chinaka, Njoku Ethelbert. 2016. 'Factors That Influence Consumer Purchasing Behavior in Nigeria', vol.4, hh.157-161.

Istijanto. 2009. Aplikasi Praktis Riset Pemasaran, Jakarta: Gramedia Pustaka Utama.

Kotler, Philip. 2003. Manajemen Pemasaran. Edisi Kesebelas. Jakarta : Indeks kelompok Gramedia.

Najah, Safinatun. 2016. Pengaruh Motivasi, Persepsi dan Sikap Konsumen Terhadap Keputusan Pembelian Produk Asuransi Syariah (Studi Banccasurance pada Nasabah AXA Mandiri dan Bank Syariah Mandiri Cabang Yogyakarta). (Skripsi). Yogyakarta : Universitas Sunan Kalijaga.

Nurdianto, Aan Romika. 2010. Analisis Pengaruh Motivasi, Persepsi dan Sikap Konsumen Terhadap Keputusan Pembelian

Sepeda

Motor

Merk 
"Yamaha” Bagi Masyarakat di Kelurahan Bendan KecamatanBanyudono Kabupaten Boyolali. (Skripsi). Solo : Sekolah Tinggi Ilmu Ekonomi Adi Unggul Bhirawa.

Priyamitra, Rully. 2012. Pengaruh Motivasi Konsumen, Persepsi Kualitas dan Sikap Konsumen Terhadap Keputusan Pembelian Toyota Avanza di Semarang.(Skripsi). Semarang : Universitas Diponegoro.

Schiffman dan Kanuk. 2008. Perilaku konsumen. Edisi 7. Jakarta: Indeks.

Sugiyono. 2002. Metode Penelitian Administrasi. Bandung : CV Alfabeta.

Suhardi. 2013. The Science of Motivation (Kitab Motivasi). Jakarta : PT Gramedia.

Sutisna. 2003. Perilaku Konsumen \& Komunikasi Pemasaran. Bandung : Remaja Rosdakarya.

Wahyuni, Dewi Urip . 2008. Pengaruh Motivasi, Persepsi Dan Sikap Konsumen Terhadap Keputusan Pembelian Sepeda Motor Merek "Honda" Di Kawasan Surabaya Barat. Jurnal Manajemen dan Kewirausahaan, Vol 10 No. 1. 